\title{
A Drum's Trans-Atlantic Journey from Africa to the Americas and Back after the end of Slavery: Annobonese and Fernandino musical cultures.
}

\author{
Isabela de Aranzadi \\ Group of Reserche MUSYCA \\ (Música sociedad y Creatividad) \\ de la Universidad Complutense de Madrid. \\ Email: isadearanzadi@terra.es
}

\begin{abstract}
Musical instruments are an intrinsic part of culture accompanying people as an essential factor in shaping the identity preserved through memory. In Equatorial Guinea there are some ethnic and social groups: Fang, Bubi, Ndowe, etc. It is in relation to the Annobonese and the Fernandinos musical culture, that the concept of "Return trip to Africa" becomes meaningful. This paper discusses this focusing on instruments such as cumbé, kunki, and dances such as cumbé or bonkó, which constitute an African legacy that has returned and has become a part of Equatorial Guinea's musical culture. The paper's main point is that the identity given by the African elements has remained active until today.
\end{abstract}

Keywords: Gumbé, cumbé, kunki, Fernandino Creoles, Annobonese, Equatorial Guinea, musical instruments, slavery. 


\section{Introduction}

Musical instruments are an intrinsic and living part of the material culture that travelled with people in their historical development. These material objects have accompanied communities which have travelled in the course of history, migrating for different reasons. These instruments are an essential factor in the shaping of identity preserved through memory, and they also form part of their spirituality. In the American continent, ritual musical objects as symbolic reinterpretation have played a role in granting not only identity but also security to communities after their brutal uprooting from their original social and physical environment. These objects have provided memories, allowing selfrepresentation and relocation through a search of stability in the home.

The search to recreate a "home" during slavery had an influence in the transmission and reproduction of instruments and music and material culture; for example, following the abolition of slavery at the turn of the $19^{\text {th }}$ century, African musical culture was enriched by contributions from newly-freed African slaves from the Americas. It entailed the return of a new sort of "African" culture to the African continent after exposure to European influences on the other side of the Atlantic. The return leg of this journey which began in the nineteenth century, spanned the twentieth century (with genres such as the blues, swing, reggae and Afro-Cuban) and continues to the present day with popular urban music in Africa drawing increasingly on external influences in a globalised world (Aranzadi 2009:36). The gumbé, a drum-dance which the Jamaican maroons "gave back" to the African continent in 1800, is the earliest example of a "return trip" phenomenon that shows all the features of African-influenced American music (Collins 2007:1).

There are social groups that have built their identities with contributions from elements that have made a return trip across the Atlantic; examples will include: the Annobonese and the Fernandino Creole people, both inhabitants of Fernando Poo (today's Bioko) and the island of Annobón respectively (Spanish colonies), the inhabitants of Clarencecity (founded in 1827), settlers from Sierra Leone and other African social groups like the Santomeans and Jamaicans (Usera 1848:18). One can also include Cuban settlers who were emancipated and deported from Cuba on many occasions between 1861 and 1897 (Unzueta y Yuste 1947:206-211) (Castro Antolín 1996:45). There is a continuous communication by sea between the little Island of Annobón and the Island of Fernando Po and this does have a profound influence on their musical culture. Of all these possible influences on Fernando Po and later on Annobón, the most important trans-Atlantic cultural currents were those that ran between Jamaica, Cuba and Sierra Leone (influences from the Deep South of the United States would also arrive in Sierra Leone).

In the case of Equatorial Guinea, two elements constitute this journey: one is the cumbélkunkilkunké, a square frame-drum adopted by Fernandino and Annobonese, which comes from Freetown Krio culture formed by three groups: Jamaican Maroons, 
U.S. settlers and slaves recaptured from different ethnic groups in Sierra Leone and other parts of Africa. The second element is the bonkó or ñánkue among Fernandino and latter adopted by the Annobonese, which came from Nigeria via Cuba (where the slaves preserved and transformed it), and directly from Calabar in Nigeria.

These musical objects are not only a reflection of a culture; they are also constituent parts of the processes of self-representation and belonging in a dynamic process of interaction of material culture and societies in motion. They represent a reconfiguration of the Atlantic culture in a complex process of social relations by the coming together of peoples in the colonial situation after the abolition of slavery. In this paper, this "return trip" is explored. The specific focus is the drum and in discussing this, attention is paid to the music that accompanies it. Both are also discussed in some passages within the context of the rituals in which they are used. The paper starts with the discussion of the gumbé and expanded in latter sections to include other drums, music and rituals.

\section{The gumbé from Jaimaica}

The first reference to the gumbe drum in Jamaica was made in 1774 by the traveler Edward Long, an English planter who lived on the island from 1757 to 1769 (Long 1774 Vol. II: 423), and is mentioned again in Freetown in the 1820s (Harrev 2001:3). Hutchinson (1861:112), the British consul at Fernando Po from 1855 to 1858, describes the goombee as one of the "immoral" dances of the inhabitants of Freetown. ${ }^{1}$ It is known by different names: gome (Ghana), gube (Mali), goumbe (Côte d'Ivoire), kumbeh (Nigeria), maringa or malinga (Congo), etc. In the Bahamas, Trinidad or Jamaica it is known as gombe, gombay, bench drum, gumbá, goomba, goombah, gamby, goombeh, goombey, goombay, gumbay, gumbe, etc. (Aranzadi 2009:144). The gumbé supplied an important building block for various 20th century African acculturated popular music genres such as the makossa of the Cameroons, or Yoruba juju music (Collins 2007:181).

In Fernando Poo (now Bioko), we can attempt to find the Jamaican legacy in two contexts: through Jamaicans who came to the island or as a result of the contribution of the Krio culture which was taken from Freetown to Clarence (today's Malabo). The black Jamaican missionaries who landed at the Island with John Clark (who supported the repatriation of Jamaican blacks to the African continent) were qualified schoolteachers prepared to educate the population (Martín del Molino 1993:103). They lived in many parts of the island between 1844 and 1846 (Sundiata 1972:170).

On the island of Jamaica, the maroons (slaves who had escaped to the mountains) used a drum known as the gumbé. They formed communities which preserved their own culture for two-hundred years in a constant struggle for survival in the face of British rule. The city of Freetown, founded in 1787 in order to accommodate the emancipated slaves, received a group of 550 of these maroons in 1800 (Rankin 1836 Vol. I: 108). 


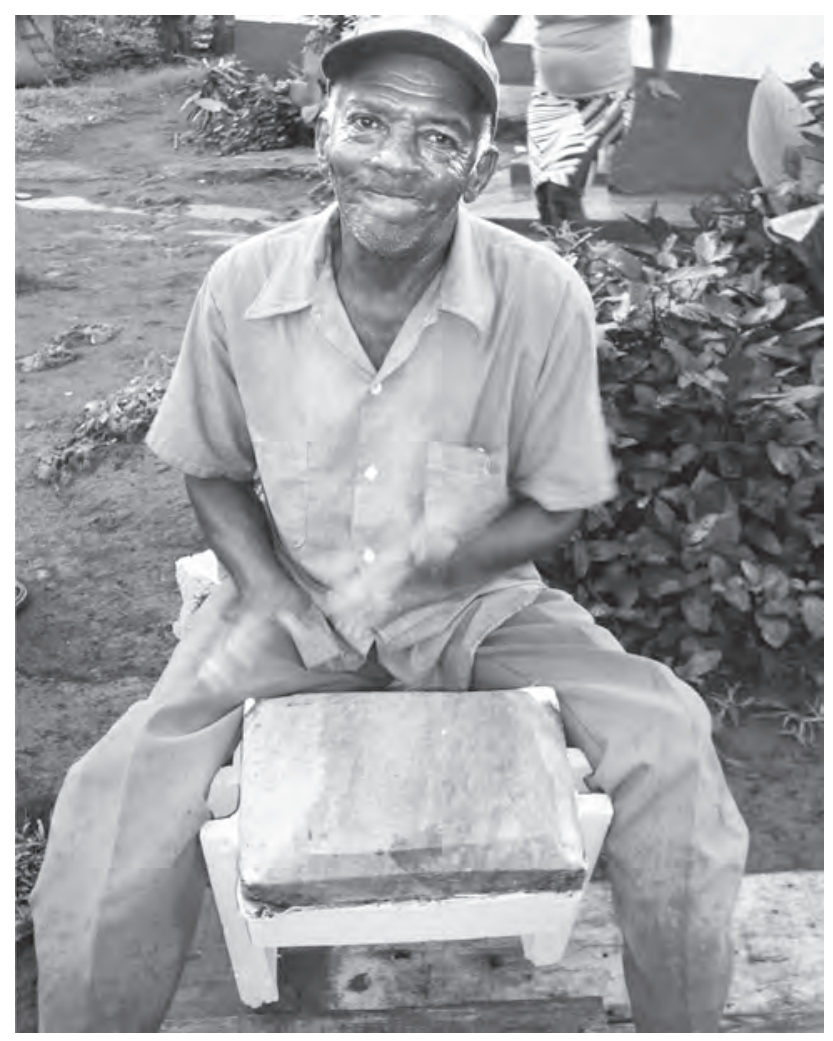

Jamaican Gumbé. Photo: Kenneth Bilby

Having been betrayed after a peace treaty, they were taken by the British to Nova Scotia in 1796 and to Freetown four years later. ${ }^{2}$ The gumbé, a square drum with legs, is an important cultural symbol for these maroons as it is associated with the invocation of their ancestors (Bilby 2007:15), and played an important role in the $18^{\text {th }}$ century, in their fight for freedom against the British. It was used for the communication of messages and also to warn them of future attacks being planned by the British. The sound of these drums provoked a trance from which these premonitions were made (Lewin 2000:160).

The gumbe is still used today by the descendants of the maroons in Jamaica. Currently the gumbé enjoys a continuing presence in Krio culture in Sierra Leone. This drum is also still used Freetown to enter into a trance and predict the future in events such as baptisms and weddings. ${ }^{3}$ Goombay has also been influential on three of Sierra Leones's $20^{\text {th }}$ century popular dance-music styles: namely assiko, maringa and milo jazz (Collins: 2007:180). 

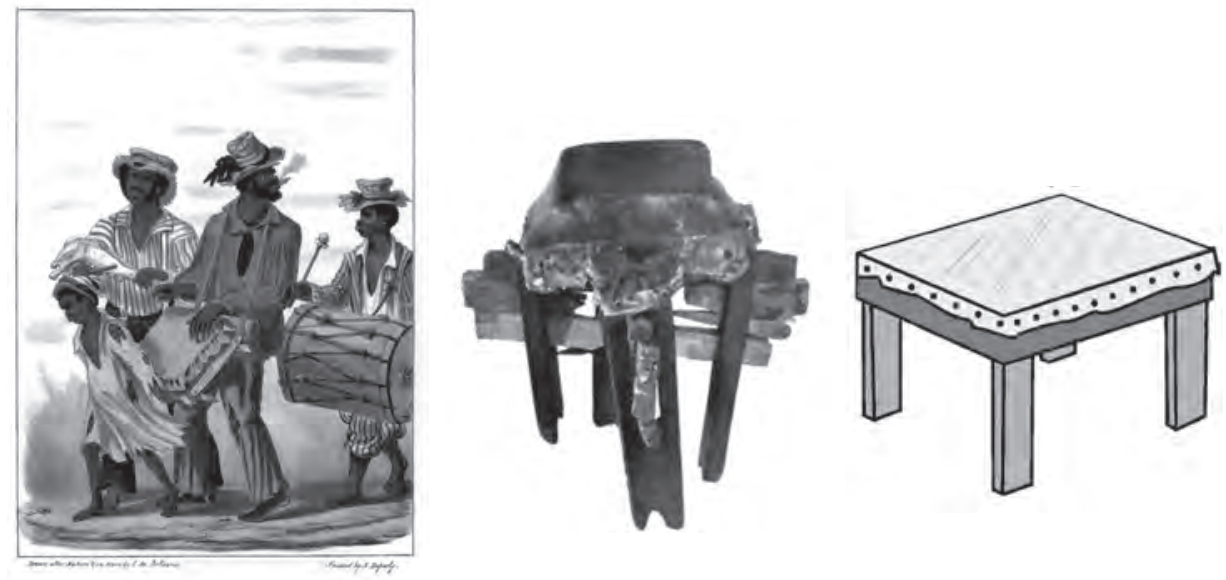

BAND A HAVY-BDNR DOHN-CANOS.

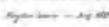

Gumbay in Jamaica

(Belisario 1836)
Jamaican Gumbé

Photo: Helen Roberts 1913

(Natural History Museum New York)
Jamaican Gumbé 1920 (Cuba) described by Fernando Ortiz.

Of the two possible routes of Jamaican influence, the most likely is that the Annobonese cumbé dance-drum arrived via Sierra Leone, since the Annobonese playing technique of using the heel of the foot is not the norm in Jamaica, where it is held between the knees. In Sierra Leone, according to Van Oven, the drum is currently played both ways (Harrev 1998 [1987]: 11). The possibility of a direct route is unlikely due to the prohibition of drums and dances by the Baptists in Fernando Po (Lynn 1984:273), however, it is clear that the gumbé spread from Freetown to several other African countries just as the Krio language (Pidgin English), which also spread from Freetown. In relation to the Krio language, one needs to mention that Equatorial Guinea has its own distinctive Pidgin (Morgades 2007:31). However, in the twentieth century, the pidgin language remained an important vehicle of communication in Bioko: "only a few spoke Spanish [in 1917]" (Bravo Carbonell 1917:46) and over 120,000 workers, mostly Nigerian (Igbo, Ibibio and Efik) were imported from the 1940s to the mid-1960s (Sundiata 1996:181-182).

\section{The Cumbé Iin Annobon}

Owing to the uninterrupted influx of workers and especially of artisan carpenters ${ }^{4}$ Equatorial Guinea would be added to the list of countries to which the gumbé would spread. It is a drum with legs and a double frame and wedges on the back to hold the drum skin taut. It is made using modern carpentry techniques with screws on the side to hold the drum skin to the frame. In addition tools such as the saw have been 
used in various countries as musical instruments including Equatorial Guinea where the Fernandino used a saw accompanying the square drum with legs ${ }^{5}$. The cumbé is part of the traditional Annobonese musical culture and was known as kunki by the Fernando Poan Creole people. The Bubi who live in the north of the island have been influenced by the Fernandino, and have used and called it kunké. ${ }^{6}$

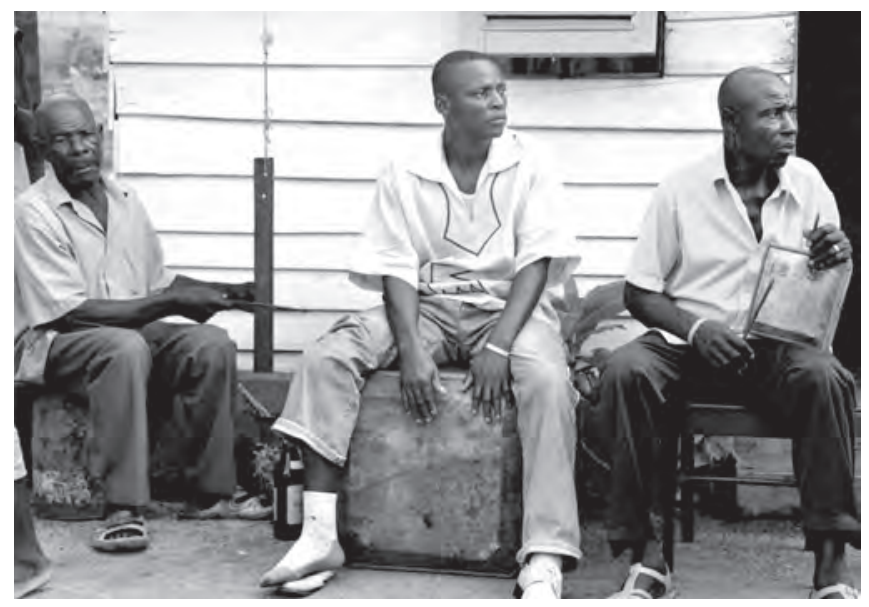

Annobonese Cumbé (with larger cumbé, little tambali and chin)

Photo: Isabela de Aranzadi

As mentioned earlier, the gumbé spread from Freetown to different countries in Central and Western Africa. Among these countries was Ghana where it has become absorbed into different musical styles as 'gome', the neo-traditional simpa music, the neo-traditional gahu music and was introduced into konkoma highlife groups" (Collins 2007: 181). A specific example would be a musical group called "Kpehe Gome Group" in Ghana which used the drum. The group was formed in 1954 with the $G a$ fishermen who returned from Fernando Po (Collins 2007:5). In fact, according to Hampton (1979) the gome was taken to Ghana by $\mathrm{Ga}$ workers returning from Santa Isabel (Malabo). It was introduced via Fernando Po in the 1940s and 50s. The songs that were accompanied by the use of the drum were in Pidgin English, sung by workers of multiethnic origin in Fernando Po, and were meant as entertainment on the day of rest, usually, Sunday (Hampton 1979:5). The Ghanaian workers learned the use of the drum and the songs from the Sierra Leonean and other West African workers who were in the city of Santa Isabel. The cumbé drum from Annobón is exactly the same as the gome of Ghana and the gumbé of Freetown, where it still constitutes a sign of identity among the krio people. A musician from Sierra Leone (grandson of the great musician Ebenezer Calender who played the gumbé), who listened to some recordings of the Annobonese cumbé, confirmed that this resembles the "old style" of goombay music in Freetown. ${ }^{7}$ Maringa, 
associated particularly with the late famous Freetown guitarist Ebenezer Calender, utilises the giant goombay frame-drum upon which a player sits (Collins 2007: 180).

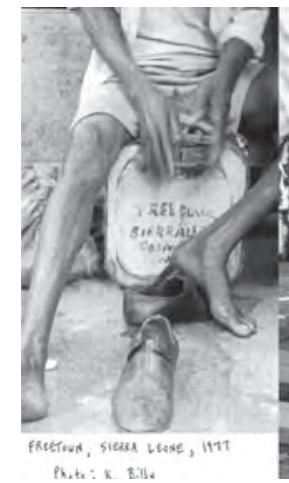

Gumbé in Sierra Leone

Photo: Kenneth Bilby

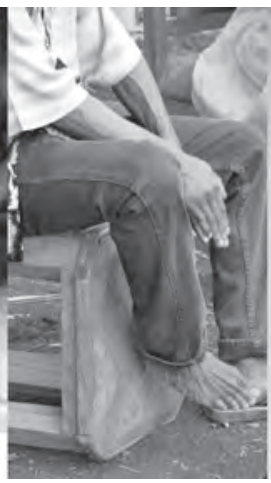

Annobonese Cumbé

Photo: Isabela de Aranzadi

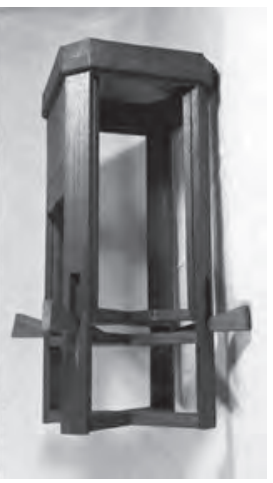

Gome in Ghana hoto: Flemming Harrev

Comparing the scores of the Ghanaian gome (Rentik 2003:35) and those of the Annobonese cumbé (Aranzadi 2009:138), we may deduce in both, the use of the afroCaribbean rhythm patterns employed in many Cuban rhythms. In the case of the Annobonese cumbé, the katá (two sticks which are struck against each other and which accompany the cumbé) produces the pattern. As far as the gome is concerned, the pattern is longer and is played by a bell.
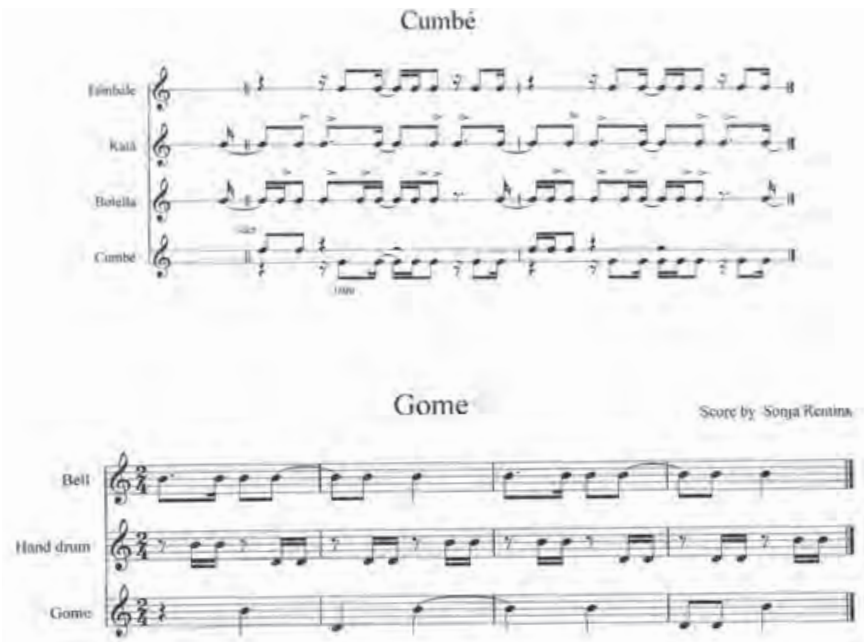
The Annobonese cumbé is a dance with a clear element of courtship, present in Europe since the age of "courtoisie" in the Middle Ages, a markedly Western phenomenon. In 1826 there is reference to a dance whose only accompanying instrument was the goombeh (gumbé) drum. Williams describes it in Jamaica in 1826 as a kind of bolero, a "dance of love" as they called it (Lewin 2000:94). The cumbé is usually danced by couples (Aranzadi 2009:144) but on the African continent it is more common for dances to be either exclusively for men or exclusively for women.

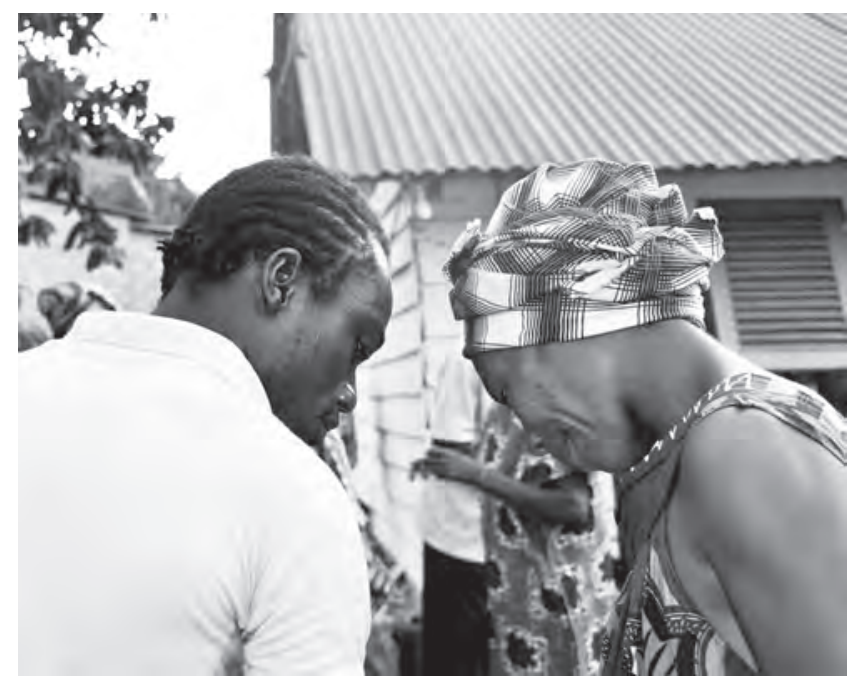

Annobonese couple dancing the cumbé in Palé (Annobón)

Photo: Isabela de Aranzadi

It is a slow dance. It begins with all participants standing still on flat ground, forming a circle, and in pairs. One of them leads the dance and can be either at the centre or in a pair in the circle. At the start of the dance men and women stand in a circle, alternating between men and women. The cumbé drum is played with only the hands until the moment known as the punt, marked by the rhythm of all the drums (the leader of the dance is called pe punt). From that moment onwards it is also played with the heel of the foot and the music acquires a greater dynamism and energy. At that moment, the women turn around and stand facing the men in pairs, when the leader of the dance gives the signal. This dance is practiced at festivals (especially on Saint Anthony's Day) and commemorations and often takes place in the town square of Palé, the most important village on the island situated in the north of Annobón (Aranzadi 2009:145).

For the Annobonese it constitutes a sign of identity and they respect it as the tradition of their elders in the same way as the other major traditions in Annobón such as sanguita ${ }^{\Downarrow}$ or dadj'i. This is a mixed age group. They perform the dadj'i dance in weddings and funerals of some members of the same age group (Aranzadi 2009:128- 
143), (Panadés 2007:117-124). In dadjì funerals, they dance with stick of the same size as the deceased's. The stick is brought out in the final death ceremonies" (Elá 2005:15). The only instrument in this dance is the little tambourine, the tambali.

For decades many Annobonese have migrated to the island of Bioko in search of work and they have preserved the dances of cumbé and dadj'i. Recently incorporated into Christian rites are some instruments such as the tambali or drums from mamahe / bonkó of Annobon such as the rolin, singing in fa d'ambô with their own rhythms. In the "Claretianos" church (Malabo) one can witness the Annobonese mass today. Each ethnic group has its own mass in its own language rhythms and musical instruments (Fang, Bubi, Kombe, Creole-Nigerian).

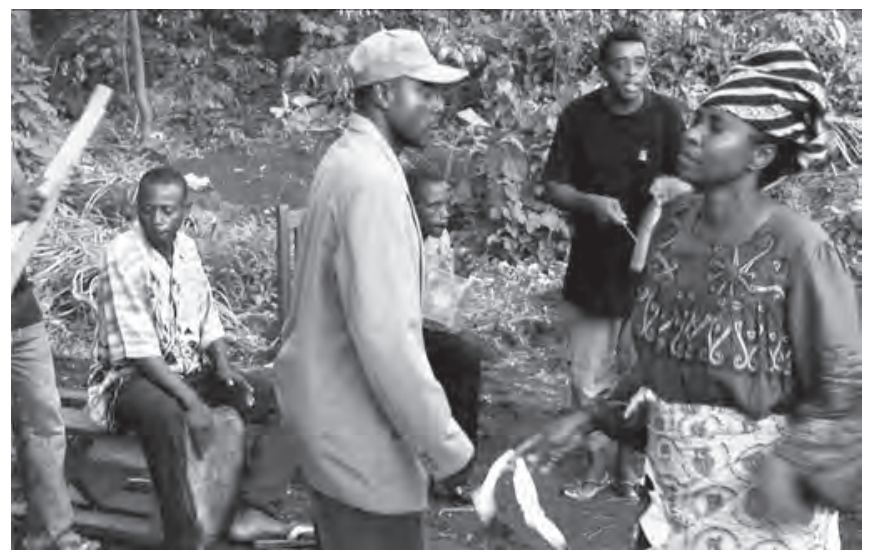

Annobonnese Cumbé. Photo: Isabela de Aranzadi

The accompanying instruments are two drums, the cumbéwhich provides the base rhythm and whose sound is deep and powerful (large in size, it is played with the hands and with the heel of the feet) and the tambali square tambourine of a similar construction as the cumbé which is played with two thin sticks (öpá tomböl). The tambali that is used is the doblá, whose sound is higher-pitched. To accompany the drums they use two idiophone instruments; the chin (iron sheet which is struck), and the katá (two thick sticks which are struck against each other). When they do not have a chin, they use bottle to produce a beat. The cumbe provides the base rhythm and the tambali makes the solos, playing polyrhythms over the ostinatos produced by the chin and the katá.

The Annobonese especially admire the elegance of the older generations in the cumbédancing. The songs have been adapted and are sung in fa d"àmbö (a Creole Portuguese). They are composed by a member of the community and are incorporated into the traditional body of popular folk songs. The transmission of knowledge to do with the handling of instruments has an initiation component, managed by a "dad" who is familiar with the rhythms and who must "bless" the person being initiated. The person 
being initiated carries an offering and will be summoned to play the cumbé from that moment onwards. "Papá Pavil'a" was the master and initiator of the few musicians who currently play this drum in Annobón and Malabo.

\section{The Bubis have no Drums but Bells}

There has been some authors such as Crespo (1950:150) and Manfredi (1949: 104-108), who describe a square drum in the 1950s among the Bubi. However, in Bubi tradition the drum has not been used. Although in some cases such as in the Aymemi dictionary, the term "drum" is translated as ribetté (1928:313), this Bubi word was used to designate the log or mölelo used in the funeral ceremony of the same name, accompanying the songs of praise. The life of this trunk was short as it only lasted as long as the funerals. The mölëlo began at sunset, firstly with the sounding of the spirit's name by the sacred trumpet. The mölëlo ceremonies lasted between four and sixteen days depending on the importance of the dead person's spirit. The trunk or ribetté or mölëlo was played furiously so as to make it "talk" and at the end of the funeral rites came the "smashing" of the trunk into pieces which was then thrown into a hidden ravine. The total disappearance of the mölelo indicated that all memory of the spirit's material presence in the world had been wiped out (Martín del Molino 1989:139-142).

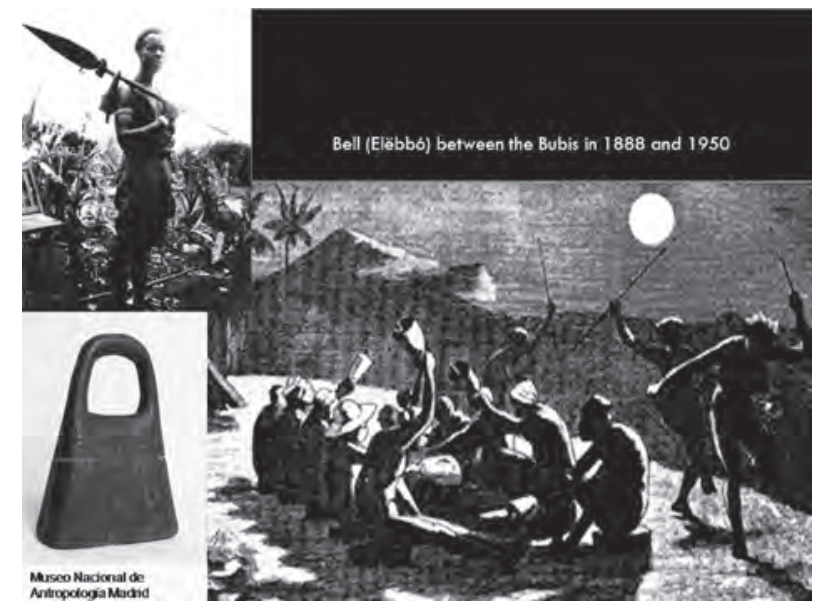

The elëbbó (Bubi bell). Baumann 1888

The Bubi drum that these authors describe in detail was therefore an acculturation from the Creoles due to the influence of a powerful group existing on the island. The Bubi have no drums, but bells. According to the inhabitants of Moka, in the south of Bioko, the drums carried by West African workers coming to the island, "bothered" the spirits 
and were banned by the elders of the village. The elëbbó (Bubi bell) is characteristic of the spirit represented by each priest. It is an identifying spiritual element and is used in the dances. It cannot be found in any other culture.

These authors refer to the same drum that is currently played in Annobón. The tambali is used as a tambourine, it has no legs and it is smaller than the cumbé. It has one drumskin and two frames held in place by wedges. In Ghana and other African countries like Mali, we find a drum identical to this and with the same playing technique, called the tamalin or tamlin.

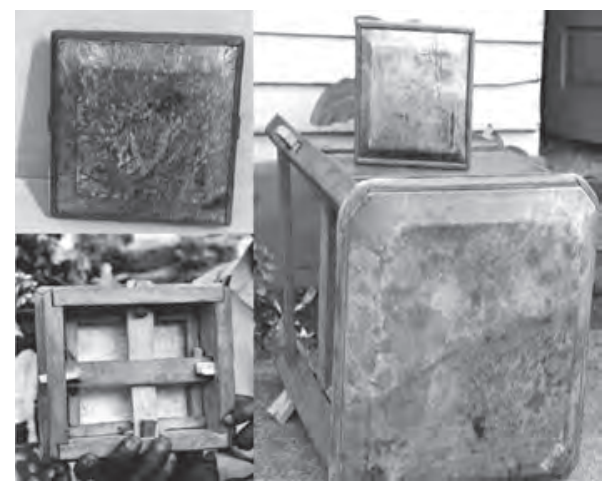

Tambali and cumbé Annobonese. View of the back of tambali.

Photos: Isabela de Aranzadi

The Museu de la Música in Barcelona holds two examples of tambourines from Spanish Guinea dating from the first half of the $20^{\text {th }}$ century (which are slighty larger than current ones). The Fernandino Creole people used this square tambourine to accompany the large, square kunki drum in the kunki dance. This small drum is known by different names in other parts of Africa: sikko (Sierra Leone), samba (Nigeria), sákara (Liberia), konkoma, etc. pletia (Ghana), tamelin, tambourim, konkoma (old Ghanaian word), ashiko, assiko (Senegal), asiko, siko, samba (Nigeria), etc. (Aranzadi 2009:205).

\section{The Kunkí between the Fernandino}

There are two elements of Fernandino musical culture which have experienced the "return trip to Africa" phenomenon, a journey which was also completed by the gumbé -cumbé - gome-kunki - kunké. The kunkídance was accompanied, by the kunki (a square drum with legs), by people who conserved the traditions originating in Sierra Leone, from 1827 (foundation of Clarence city), onwards. The Fernandino had a continuing relationship with Sierra Leone and sent their children to school in Freetown (Navarro 1859:73). The koonken or koonking (the English spelling) was danced in 1830 Freetown by the settlers and has been described by some authors. It is described by the traveler 
Rankin (1836: 268) and Sibthorpe in his History of Sierra Leone (1970[1868]:52). It arrived from Nova Scotia (Canada) in 1792 with the 1131 freed slaves who had taken part in the American War of Independence on the British side and who had originated in Virginia and South Carolina Rankin (1836:82-87). Some of their songs were brought with them from America and others were created in Freetown and were often satirical in nature and on such subjects as love and loss, and also contained allusions to known (and also white) people (Walker 1976: 310-311), (Rankin 1936:288).

The contradiction operated in memory of its musical culture as a repository of different identities and always in relation to "other." Following the need to assert their Africanity in relation to "other" Europeans in America, which represented numerous prohibitions on the use of drums prior to 1700 (Epstein 2003 [1977]: 30), in their return to Africa they continued to maintain a differentiation in relation to "other" Africans they considered inferior (under the influence of colonizers):

\begin{abstract}
"...We rejoiced at the thought of returning to the warm and fruitful land of our race, able to draw from its inexhaustible resources the treasures of which our negro brothers who dwelt there were so ignorant; and we felt a pride in considering that we were blacks about to revisit the country of savages, with some small 'stock' of education, and that we might lead others to improvement." (Rankin 1834:87). ${ }^{12}$
\end{abstract}

The word 'stock' is significant and describes the content (in) material that they brought with them in as a privileged social group facing the black Africans. The kunki survived in Santa Isabel (today's Malabo) until the 1970s and was part of the culture of the descendents of the first Sierra Leoneans. It was sung at major events such as weddings, baptisms and komodja (old Yoruba term used to describe the traditional christening or pulnadö, which now comes from pidgin for to pull out of the door, i.e. the newly out-born-out of the door, literally). The pulnadö is the initiation ceremony for social integration of a newborn between de Creoles in Malabo. ${ }^{13}$

The Fernandino accompanied it with three square drums: the kunki (this was a large drum, fifty centimeters across, and had four legs one meter in length) and two small, square tambourines (of fifteen and twenty centimeters across) built in the same way, called tambali, one of which was higher in pitch so as to produce lively rhythms and polyrhythm's, and the other as accompaniment. It was also previously accompanied by an accordion, a saw and a bottle. Women wearing long dresses of a single solid color that came down to the ankles performed the dance in circular formation (as in Freetown), while the men played the instruments. It is similar to the Annobonese cumbé dance, but this one has a more "fiery" rhythm. ${ }^{14}$ In 1971 there were three women's associations, since for the Fernandino this is a women's dance (as in Sierra Leone in 1830). The square kunki drum was played (as is the case today with the cumbe and the gome), with the drummer sitting astride the four-legged drum. 


\section{The Bonkó From Nigeria/Cuba To Fernandopo}

The other element of Fernandino musical culture that was involved in the "return trip to Africa" phenomenon is the bonkó or ñankue, ritual-dance that is practiced today from mid-nineteenth century in Bioko, later introduced in Annobón at the beginning of the twentieth century, under the name of mamahe. This dance can be found on the island of Annobon for three generations, introduced in the early twentieth century from Santa Isabel, by Ton Bale. It is a ritualistic dance that comes from the Efik people in Calabar (Nigeria) and transformed in Cuba before come back to Fernando Poo. Both the bonkó and the ñankue refer to the same dance and came to Bioko ${ }^{15}$ directly from Nigeria with the Efik and indirectly from Cuba with the deportees and freed Cubans. According to some members of the secret society of Bonkó, including their descendants, Daniel Nathaniel Kinson took the dance in the mid-nineteenth century to Santa Isabel. He married Sara Robinson, an Efik Nigerian woman dancer who introduced elements of the rite. She was initiated in Efik rites in Calabar and their son Samuel Norman bought a high grade in the Ekpe hierarchy. He was initiated in Nigeria. According to Diego Kinson, (great-grandson of Daniel Nathaniel Kinson):

\footnotetext{
"They went to Duala and traded in palm oil. Betoté Akwa was a Duala, the first king of the Akwa, and his sister married Kinson [her was the first wife]..."There were two kinds of Sierraleoneans. Some brought American traditions such as the kunki (they also danced the Charleston), and others (non-slaves from Sierra Leona), they danced the Basá ñankue. The creoles called it the ñankue of the Basá"... "They all came from Sierra Leone, but with different status"... "They wore a raffia costume similar to the mekuio"... "My father knew the rituals of Nigeria and belonged to the Ekpe. The black loyalists founded the masons to which the great grandfather and the grandfather belonged"... Daniel Nathaniel Kinson ${ }^{16}$ brought Mendé people (a tribe from there)" ${ }^{17}$
}

The Sierra Leonean people practiced as teachers (along with the Fanti of Ghana) of newly freed slaves as they arrived to the island after being rescued from captured slave ships (Martín del Molino 1994:62). ${ }^{18}$ Most of these slaves, recaptured during the 1820s and 1830s, were from the region of Calabar in southern Nigeria (Lipsky 2004:9). Migrations from Sierra Leone also drastically increased the population of Fernando Poo.

The secret society Ekpé from southern Calabar met in the Nigeria-Cameroon frontier area before borders were established (Sosa 1982: 32,62), and was exported by slaves to Cuba, where it became known as Abakuá. Thanks to the cabildos, ${ }^{19}$ the language, traditions, musical culture and rituals were maintained among the African slave population. The cabildos were the heirs of the religious cofradias ${ }^{20}$ of Seville and they allowed unity among the "negros de nación" (blacks of the same origin). The feast of the Epiphany (Three Kings' Day) was the most important religious and cultural for blacks in Havana. The 
funeral ritual of the secret society Abakuá is known as nánkue or ñankpe in Cuba. In Nigeria nyankpe is one of the highest ranking positions in the secret society Ekpe or Egbo. Holman (1834:393) also mentions the position of yampai ${ }^{21}$ as high-ranking in the Nigerian society called Ekpe, or Egbo, described by some other authors in the 19th century as Goldie (1901:30) and Mary Kingsley (1897:532) among others.

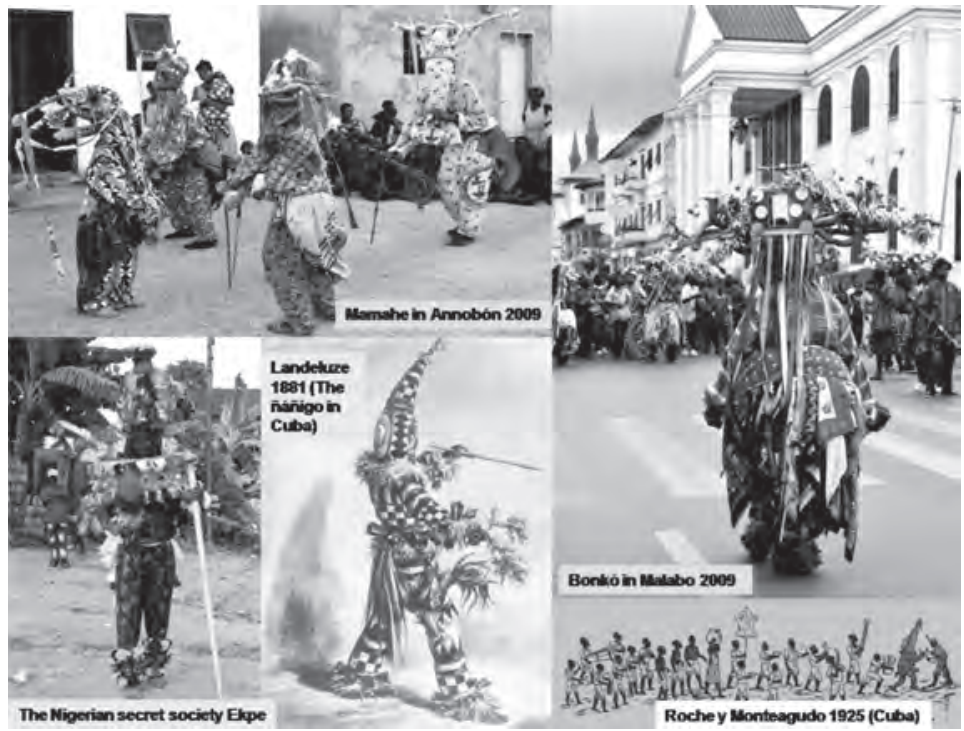

Bonkó dance in Malabo (Bioko). The ñankue mask. Comparison with Nigeria/Cuba. Photos Malabo and Annobón: Isabela de Aranzadi. Nigerian: www.afrocubaweb.

In the bonko dance ritual there are many elements inherited from the ritual of the Nigerian secret society Ekpe, transformed and known as Abakuá in Cuba where there are the funerary rite ñankue, which celebrates the secret society. The Abakua is a hierarchical society and therein, the irimes or masks also represent the ancestors and spirits performing different ritual functions in some ceremonies (Cabrera 2005 [1959]:9, 16, 261). On the other side of the Atlantic, among the Fernandino creoles, the whole development of the dance in Malabo is carried out over the Christmas period, with the Epiphany being a very important day, as it was in Cuba. In Santa Isabel "deported Cubans practiced ñankue. It was a kind of demonstration against the colony". ${ }^{22}$ The dance finishes with a salute to the authorities. It is these days taken by the President Obiang but in the Spanish colonial era would have been taken by the governor (as in Havana). One of the bonkó masks in Malabo, with three African faces, Papá fero, represents evil. They carry this character tied with a chain to symbolize that evil is not to be part of the community, like among the Cuban Abakuá where the írime is tied and led by Enkrikamo. The word irime comes from the Efik word idem (mask). 


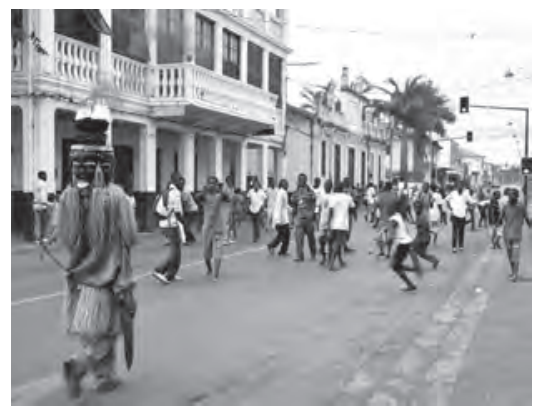

Papá Fero tied to a chain following young people in the city of Malabo.

Photo: Isabela de Aranzadi

The costumes in Nigeria are adorned with small bells called enkaniká (Miller 2005:25). ${ }^{23}$ The nánkue is in Bioko the main character and dancer of the Fernandino Creole people who has bells dangling around his waist, and makes them sound, like a symbol of power, and the dance acquires greater energy through his skill. It is called bonkó in Malabo and some Bubi villages. It was also exported to Rio Muni and is practiced in some Fang villages under the name of abakuya. ${ }^{24}$ The mask has evolved depending on the village. They have a president and the members of the association are initiated by a person versed in the rite, song and dances and there are many women who sing in Pidgin English. The rhythm is different and has been adapted to the Fang style. ${ }^{25}$

The town of Santa Isabel received exiled Abakua as well as Efik merchants who were Ekpe. In 1828 Great Duke Ephraim, in 1861 King Eyo III and in 1874 the trader Efik Joseph Hensaw (Miller 2009:127). Muñoz y Gaviria describes this visit (1950: 208210). Many workers were later to the island.

"In contemporary Calabar, the memory of those who left for Fernando Po to find work on plantations in the nineteenth century remains strong. In the 1980s, a group of Ekpe musicians recorded this popular phrase:

Ete unyeneke ubok utom

Anana ubok utom di ika Panyá. you say you are unemployed

If you are jobless let's go to Panyá.

Panyá is a rendering of the name España (Spain) into some local English varieties of Nigeria and Cameroon" (Miller 2009:128).

The dancer (ñánkue), is accompanied by the five bónkó drummers who play vigorously and engage in dialogue with the dancer in the centre. The ñánkue has an uncanny similarity with the Cuban irime of the Abakua society, described and recorded at the time.

We can observe the evolution of the costume and mask of the dance by comparing 
four moments in history on both sides of the Atlantic: in Nigeria, Cuba, Anobón and Malabo. In Nigeria the tradition survives today of using a pointed hood that is also observed in the engravings and pictures in Cuba in 1870 and in the early twentieth century (Landaluze 1881:141) and (Roche Monteagudo 1908). In the 1900s and 1910s Jones described it in the same way (1962:243). Subsequently there is testimony of the transformations in Malabo involving the addition of some "tentacles" called "horns" and there are some descriptions in 1950s (Álvarez 1951:222). The hood can still be seen in Annobón, although some small "tentacles" have been added to the head. The bonkó (mamahê) reached this island one hundred years ago and as a result of isolation, the evolution was less notable (ships visited the island once a year). Finally we see the evolution in Malabo, where the transformation results in a pointed hood filled with much more "tentacles" or "horns" and many bright Christmas decorations and many small mirrors. In the costume one can also see the influence of the Abang female dance in the prominence of the back part, from which many handkerchiefs hung. Its body is covered with plant fibers and this is observed as early as the 1920s (Arija 1930:137). In Annobón the costume has been conserved just as it was formerly used in Malabo, according to the Annobonese who had lived on both islands.

Another term of Efik origin is the word for the bell used in the rituals, a bell without a clapper, which is played with an iron rod, accompanying the drums and producing a rhythm distinctively Caribbean in character. Among the Fernandino it is called the könkön (Aranzadi 2009:166, 261). In Efik the term is $a-k a \tilde{n}-k a \tilde{n}$ (Sosa 1982:403).

One of the drums which they use in the bonkó or nánkue dance is called the rolin. According to the Fernandino, this drum arrived on the island with $19^{\text {th }}$ century Cuban deportees. These Cubans lived in Barrio de los Congos and later, by 1873, had been assimilated into the Fernando Poo Creole English-speaking population (Díaz Matarranz 2005:118). One of these Cubans wrote that there were some musicians among the group of his fellow deportees with him, on the same boat (Bravo Sentíes 1869:99,103). By 1891 there were some Cubans within the landowning class (Sundiata 1972:231). ${ }^{26}$ Esteban Montejo ex-slave and Cuban maroon recounts that some ñañigos (members of the Abakuá secret society) were taken to the Island of Fernando Poo from Cuba (Barnet 1966:90). In 1869 the deportee Juan Saluvet described dances that he saw in Fernando Poo that resembled those of the Cuban cabildos, with their drums, rattles and castanets (Saluvet 1930[1892]:144). Another Cuban deportee compares Sundays in Santa Isabel with the Epiphany in Havana (Valdés 1898:67). 


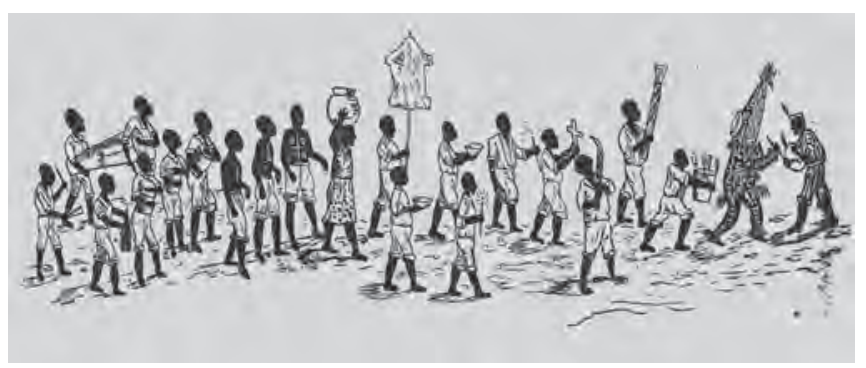

The ñañigos in Cuba in 19 ${ }^{\text {th }}$ century. Roche y Monteagudo (1925[1908]:99)

The Cuban deportee Manuel Miranda speaks of a significant number of ñáñigos who arrived in 1897, singing in ñánigo and using spoons to play jars and plates. He also describes how Cubans and Sierra Leoneans gathered together in a the same balele ${ }^{27}$ in the city (Miranda 1903:12-16, 31). The word ñinigo is used by the Fernandino creole people in the rules of the ñinigo ñankue ${ }^{28}$. The sense of the sacred, the search for the Africanity, the spiritual consideration and the connection with the ancestors is common to both sides of the Atlantic. This dance of funerary origin has a component, of memory, of remembrance, and is intended to honour ancestors ${ }^{29}$. The objects (drums), are part of this symbolic and ritual content.

Fernando Ortiz states that the drums that Mary Kingsley describes in Fernando Po in 1897 (Kingsley 1897:67). were of the "Duala type", similar to those of the Cuban ñánigos and introduced by the Afro-cubans.

"... when many of them took their liturgical dances with them to Fernando Poo, such as the dance which today is known as the Fernandino yangue, which is a funeral dance originating in Calabar (ñankpe or ñankué means "death" in the nánigo language), and which the people of that nation brought with them and established in Cuba. Their children, many years later, having adopted this tradition, would later return it to Africa." (Ortiz 1996 [1952]: 322).

The Ékue society uses the Ékue drum which, as Fernando Ortiz describes (1995:5), is a friction drum with a sound box and a drum skin held in place by wedges and rods. The Ékue drum is rarely seen and it is only known to certain initiated members. It is recognized by its rough and mysterious sound that evokes the terrifying roar of a leopard or the deep voice of great mystery. Hugh Goldie notes that at the end of the 19th century the Efik people of southern Nigeria believed that the Ékue (Ekpe or Egbo) ${ }^{30}$, which means leopard, occupied the highest spiritual rank and supreme territorial power. Its name cannot be uttered, its voice sounds like the growling of a ferocious animal, and it is never seen because it is brought out from the woods hidden in a sort of small shed (Goldie 1901:30-32). Similarly, Mary Kingsley, in her chapter on secret societies, amongst which we find the Ukuku ndowe and the Egbo in Calabar, she describes the 
sound of this "hidden" being that represents the highest rank in the spiritual hierarchy (Kingsley 1897:534). These societies have played a judicial role (Perrois 1979:47) of social regulation in the same way as the Mekuio (Ndowe) (Aranzadi2009:99) or extinct Ngil (Fang) (Alexandre 1958:63).

The Ekué drum is used in the Cuban secret society Abakuá, for whose members the most important objects are symbolic drums which perform a ritualistic function. It is the sacred instrument, where the voice of the divine spirit its heard. It is also used in certain ceremonies of the Fernandino Creole people. The society of bonkó has a special fiction drum that is used in the crai Egbo ceremony (where they lament the death of a brother, a member of the bonkó society).

\section{Processes of the Reception of Musical Elements}

On the island of Bioko, formerly Fernando Po, there are processes of reception and appropriation of musical elements such as rites, songs, instruments, and clothing for dancing, etc, as symbols that give an identity sought for its direct relationship with a powerful group which, when it modified the social space, exerted its influence through culture. This is the case of the Fernandino creoles in a historical position of authority in the social structure for its socio-economic power. In 1843 they formed the City Council and Lerena gave them wide powers of control over Santa Isabel and in the surrounding area (García Cantús 2004:175). In 1840 they lived in the town 900 "civilized" blacks and only 15 Europeans (Guillemar de Aragón 1852:61). In 1897 the Fernandino Daniel Nathaniel Kinson who, according to the Fernandino, brought the dance of bonkó, belonged to the "Consejo de vecinos" (he was second mayor) in Santa Isabel, and is described by one of the deported Cubans (Valdes 1897:35).

"Its community extended from the city of Clarence, later Santa Isabel and Malabo nowadays, around the coast of the island during the nineteenth century. The Fernandino would be the pioneers of trade on the island by establishing trading posts and plantations of tropical crops, a point of attraction, a symbol of progress and a factor that would make Clarence and later Santa Isabel a cosmopolitan city." (Sundiata 1996:182).

In some Bubi villages in the north (Baney, Rebola, Basakato) or near Luba (Barrio Las Palmas, Batete) they have introduced the rite of bonkó, characteristic of the Fernandino Creoles in a acculturation that occurred by the continuous contact between the two cultures in the mid nineteenth and early twentieth century, the period in which this ritual dance starts and develops on the island. There are testimonies in 1890 of the ritual dance "as a manifestation of non-Westernization of this community, in a letter from a Creole Fernandino called Barleycorn” (Sundiata 1996:151). Also, the use of the dual frame, four legged drum called kunké expands amongst the Bubi people of these towns 
and in the city itself, through contact with an influent group in the social structure.

We see the "return trip" phenomenon in the case of the bonkó, since Efik culture (of the region of Calabar in the south of Nigeria) arrived in Fernando Po via Cuba, where Efik people were taken as slaves. The Annobonese mamahê dance comes directly from the bonkó or ñankue dance of the Creole people retains some ritualistic elements .

We also find loan words in musical terminology. The rolin is a drum that is used by some groups in Guinea. In Jamaica the maroons of Moore Town have a drum called the rolling. In Sierra Leone the same term rolling is used for one of the square drums that make up the sikko group of instuments. Katá is a term used by both groups (Annobonese and Fernandino creoles), to designate the sticks which are struck together as an accompaniment. In Jamaica, katá is the name of the sticks which accompany the drum among the kumina people (non-maroon African Jamaicans). In Cuba the term katá denotes two bamboo sticks which are struck together as an accompaniment. There are also some efik words in songs in Malabo In Malabo songs (some in pidgin and others in Spanish), some terms are preserved from Efik such as Abasi (Aranzadi 2009 b:18). In the legend relating to their origin (Sosa 1998:317), the Abakuá refer to the princess Sikan, the daughter of the Efor people. One day she approached the river to collect water in her pumpkin. When she was filling it, she accidentally caught and killed the sacred fish Tanze, the voice of Abasi (the supreme deity) and holder of the great mystery (also called Uyo). As a punishment for her profanity, Sikán was ritually sacrificed and her skin was used to cover the first sacred drum (Ekue), which only a select few could see. Other term is Dibo, repeated in many moments during the procession. It refers to Divine Voice. The maringa is a song of Cuban influence that the Fernandino sing at the end of the bónkó ritual-dance and the Annobonese sing at the end of the mamahê (it is the term in Annobón for the Fernandino bonkó). In Gabon the word maringa is understood to mean a large, square tambourine played with the heel and the same term is used for the songs and the dance that are accompanied by this drum (Pepper 1958:49). González Echegaray (1956: 26 and 1964:149) classifies the maringa as a Cameroonianinfluenced guitar song with a markedly Cuban feel due to deportees and freed slaves who established themselves on the island. It is a dance practiced by the Fernandino, as Daniel Jones notes in his novel Una lanza por el Boabi (1950: 146) and as do other authors in the early $20^{\text {th }}$ century (José Más 1931 [1919]: 96). From the $19^{\text {th }}$ century onwards the maringa was practiced independently of the bonkó. At first with an accordion and later with the guitar always accompanied by the large, square kunki with legs, and also by the small, square tambali tambourines. Nowadays the dance of bonkó and also mamahê (is the bonkó in Annobón) are rounded off with singing maringa. 


\section{Conclusion}

Material culture elements such as instruments, dance and songs, have made it possible to maintain alive the memory of who they were, where they came from and who they were connected to. They have also helped establish a symbolic bridge to their original parentage. The identity given by the African element has remained active until today. Firstly, as we have seen, among the slaves in the Americas. Then, among the freed slaves when they returned to their "home areas". This took place from the late eighteenth century onwards, as the multi-ethnic society that was originally created in Freetown,

"...when the Krio community embraced the church and other institutions introduced by Europeans there was little room for their own culture and the gumbe answered this need, becoming over the years the dominant musical style, serving to unite the different peoples from the Krio culture." (Harrev 1998 [1987]:9).

Later, this identity lived on, when they expanded in Africa reaching Fernando Po from 1827, as a symbol of the Creole culture that was even exported from Santa Isabel to countries such as Ghana. Finally when, under the influence of this island, it also reached the remote island of Annobón and these elements became an important part in the Annobonese musical culture.

Peoples who are physically remote but close in their identity are connected (Jamaican maroons, blacks in the south of the United States, Settlers in Freetown, groups of recaptured slaves, Africans from different parts of the coast, Fang from Equatorial Guinea, Bubi from the island of Bioko, Fernandino creoles from Malabo, Annobonnese from Annobón, etc).

On the islands of Bioko and Annobón there has been a "return trip" phenomenon insofar as dances and musical instruments are concerned. Although they have European influences, they are African in character (liturgical song, syncopated rhythmic patterns and with polyrhythms, dancing in circles, etc.). Instruments such as the cumber, the kunki, the tambali and dances such as the cumbé, the kunki, the bonkó, the mamahê and the maringa, constitute an African legacy that has returned from America, a "return to Africa” within Equatorial Guinea's musical culture.

Dedication: To my father, Íñigo de Aranzadi, who lived with the fang, learning their language and recording their traditions, and who was made an adoptive son by Etó Mebimi from Abere Esatop.

Acknowledgements: Flemming Harrev, Kenneth Bilby, Diego Kinson, Teobaldo Kinson, Trinidad Morgades, Kole Vivour and Desiderio Cervera Liso (a great Annobonese musician who we know as Desmali). 


\section{NOTES}

1. The quotes are mine.

2. The ethnomusicologist Kenneth Bilby gathered oral testimony over three decades on this event in the past, recounted by Maroons elders in Jamaica (Bilby 2008: 378-390).

3. Seydu (a musicien from sierra Leona) in personal communication 2010.

4. Flemming Harrev (1993: 6), (2001:7) and in a personal communication in 2008, pointed out to me the contact and the possible cultural influences between workers in West and Central Africa. "In the Belgian Congo alone 5,000 West Africans were recruited in the 1890's to construct the railwayline from the Atlantic port city of Matadi to the present day Kinshasa. He points back to Freetown - the capital in the first half of the 19th century of all the British West African territories (Banjul, Freetown, Fantiland, Lagos and Fernando Poo), and its unique, at least to Africa, Krio (or Creole) culture - as the focal point for the development of these early styles of urban music and dance". It is also quoted by Collins (2007:184). Clarence City was rapidly built with the wood brought by Owen from Freetown (Ríos 1844:61). The only craftsmen were carpenters in the 1840s (Usera: 32). I consider this factor to be very important because the African workers with their expertise in carpentry were the ones who were and are versed in such a sophisticated technique as the construction of this drum (in Malabo today there is a carpenter and musician named Hipólito Teruel who builds this drum). Freed slaves and creoles possessed this knowledge involving many technical skills, learned from the Europeans who hired them in different parts of Africa during the early colonization.

5. The saw was also played in Annobón with the box, the tambali and the bottle. Juan Murcia (President of the cumbé) still plays it today.

6. Aranzadi $(2009: 37,74,137,160,205,261,278)$ and Elá $(2005: 32)$. The Bubis also use the word kunké for a little square drum similar to a tambourine called tambalí by the Annobonese people.

7. Seydu is a musician from Sierra Leone, the great musician Ebenezer Calender was his grandfather who played maringa and the old style of goombay music in Freetown. (Personal communication 2010).

8. This rite is a Christian syncretism which originated as a spiritual need as a response to the abandonment by the Portuguese for many decades during the colonization on the island. See Zamora Loboch (1962), Caldeira (2005:10) and Aranzadi (2009:128-130).

9. In Malabo they play the bottle making the same rhythmic pattern as the katá. The big cumbé with legs is larger than in Annobón, where it is similar in size to the Jamaican goombay. 
10. Isidro Lisso Alzina was born in 1918-1920. Another master was Gregorio Lisso Muñoz, born in 1932 (Desiderio Lisso personal communication 2008).

11. Nuria Fernández (personal communication 2006).

12. The quotes are mine.

13. Morgades personal communication 200. This ceremony is described in Sierra Leone in the period 1827-1828, among Yoruba liberated slaves (Sibthorpe 1970) (1868: 52).

14. Described by Diego Kinson (Creole Fernandino descendant of a Sierra Leonean who arrived in Fernando Po in the middle of the 19th century), in a personal communication in 2008.

15. The first reference to the relationship between the "yangüe fernandino", the "ñáñigos cubanos" and the "Calabar inglés" was made by Moreno Moreno (1948:83-84).

16. The Spanish Ministry of Foreign Affairs possesses the document signed by King Alfonso XII awarding the Medal of Isabella the Catholic to Daniel Nathaniel Kinson in 1902 when he was seventy three years of age. His son Samuel sued Mayo because they would not emancipate him, he being a son of a Knight of Isabella the Catholic.

17. Diego Kinson (personal communication 2010).

18. "Los sierraleonas [...] se erigieron en maestros (junto con los fanti de Ghana) de los nuevos esclavos liberados que iban llegando a la isla, tras ser rescatados de los barcos negreros capturados".

19. In this Cuban colonial context a 'cabildo' denotes a group of slaves of common ethnicity, who maintain and transmit their traditions in the language of their ancestors and who would gather to celebrate on festive occasions according to the traditions of their places of origin.

20. Brotherhoods.

21. Observe the similarity between the words: $y a m p a i=y a m p e=$ nyampe $=$ naankpe $=$ nya nkpe=ñánkue=yangüé, etc.

22. (Teobaldo Kinson personal communication in 2007).

23. Ivor Miller, a research fellow in the African Studies Center of Boston University has made a re-encounter between Cuba and Africa. "That's why it's extraordinary that the Ekpe in Calabar can listen to a speech by the Abakuá, or music and chanting, and understand it and recognize the rhythm and many of the words. The Ekpe system has nine different grades. One of those grades is called bonkó. Bonkó in reality represents the universal mother, the myth of the woman in the origin of the legend". See more on an interview with I. Miller (2007).

24. Note the similarity with the Cuban term!.

25. Felipe Osá (in a personal communication in 2009).

26. The Kinson were among them (Sundiata 1974: 98) and (Sundiata 1996:93,169, 
187, 217, 248). See also Clarence-Smith (1994:183).

27. Colonial term to describe the dances of the blacks.

28. The ñiñigo ñánkue is the name appearing in the statutes of Bonkó society to refer to the Bonkó. With this term they refer to the dance as a whole: masks, drums and costumes.

29. Homage is paid to the dead by the Bonkó on December $24^{\text {th }}$ in the cemetery, December $31^{\text {st }}$ in the old cemetery at Santa Isabel (under the asphalt of a street in the present-day Malabo) and on the morning of the $25^{\text {th }}$ visits are paid to the houses of bereaved people belonging to the Bonkó society and Basilé wher many members of Bonkó society died in an accident some years ago.

30. Egbo is the highest hierarchical grade in the Bonkó society. According to tradition, this post was occupied by one single person known as big Egbo (as with the Efik). It is currently a council comprising ten people. This council runs society, judges the members thereof and draws up the statutes.

31. Teobaldo Kinson's personal communication.

32. The initiation and the punishments are performed in the Bonkó is meted out over the five drums. In Annobón in January 2009 I observed that a long and supple saw is used to beat the soles of the feet. Those punished are the ones who did not attend the call after Mass to start the procession of Mamahê through the town of Palé. This event takes place in the big square hut used as a meeting place by bonkólmamahê society, following the maringa songs and dance that closes the procession, the dancing and the singing. It presents a characteristic Annobonese jocund context, but no age or any other condition is excused.

33. Miller (2009: 43, 56, 57, 180, 206. 211, 216, 238, 290, 349, 352).

\section{References}

Alexandre, Pierre et Binet, Pierre, Jacques, 1958, Le groupe dit pahouin fang boulou - beti. Presses Universitaires de France, Paris.

Álvarez, Heriberto Ramón, 1951, Leyendas y mitos de Guinea. Prólogo de Antonio de la Nuez Caballero. I.D.E.A Madrid.

Aranzadi,Isabela de,2009,Instrumentos musicales delasetnias de Guinea Ecuatorial.Madrid, Apadena.

Aranzadi, Isabela de, 2009 b, "Música y palabra”. Palabras. Fundación España Guinea Ecuatorial, No. 1, 2009, Madrid.

Arija, Julio, 1930, La Guinea Española y sus riquezas. Espasa Calpe. Madrid.

Aymemí, R.P. Antonio, 1928, Diccionario español-bubi. Editorial del Corazón de María. Madrid.

Barnet, Miguel, 1966, Biografía de un cimarrón. Academia de Ciencias de Cuba. Instituto de Etnología y Folklore. Año de la Solidaridad. La Habana. 
Bilby, M., Kenneth, 2007, The Legacies of Slavery and Emancipation, Jamaica in the Atlantic World. Yale University, New Haven, Connecticut.

Bilby, M., Kenneth, 2008, True-Born Maroons. University Press of Florida. First edition, 2005.

Bravo Carbonell, Juan, 1917, Fernando Poo y el Muni. Sus misterios y riquezas. Prólogo de D. Tomás Maestre. Imprenta de "Alrededor del Mundo". Madrid.

Bravo Sentíes, Miguel, 1869, Revolución cubana. Deportación a Fernando Poo. Relación que hace uno de los deportados. Imprenta de Hallet de Breen. Nueva York.

Cabrera, Lydia, 2005, La sociedad secreta abakuá narrada por viejos adeptos. Tercera edición, Miami, Universal. $1^{\text {a }}$ Edición, 1959.

Caldeira, A. M., 2005, "Medo e religião popular na ilha de Ano Bom. Uma aproximação histórica séculos XVI-XIX”. Centro de História de Além-Mar, FSCH/ $\underline{\text { UNL. }}$ Actas do Congresso Internacional "Espaço Atlântico de Antigo Regime, poderes e sociedades» Lisboa 2 a 5 de Novembro de 2005, FCSH/UNL

Castro Antolín, Mariano de, 1996, La población de Santa Isabel en la segunda mitad del siglo XIX. Asociación Española de Africanistas A.E.A. Cuadernos monográficos, Madrid.

Castro Antolín, Mariano de, 1994, "Fernando Poo y los emancipados de La Habana". Estudios Africanos, Revista de la Asociación Española de Africanistas A.E.A. Vol. VIII, no 14-15, Madrid.

Clarence-Smith, W. G., 1994, "African and European cocoa producers on Fernando Poo, 1880s to 1910s". Journal of African History 35, 1994, pp.179-199. Cambridge University Press.

Collins, John, 2007, "Pan african Goombay drum-dance music, its ramifications and development in Ghana", Legon Journal of the Humanities, eds. Gordon Adika \& Kofi Ackah. Published by the Faculty of Arts, University of Ghana Legon. Vol. XVIII, 2007, pp. 179-200,

Crespo Gil-Delgado, Carlos, 1949, Notas para un estudio antropológico y etnológico del bubi de Fernando Poo. Instituto de Estudios Africanos y Bernardino de Sahagún de Antropología y Etnología. C.S.I.C. Madrid.

Díaz Matarranz, Juan José, 2005, De la trata de negros al cultivo del cacao. Ceiba Ediciones. Barcelona.

Elá Nsué Mibuy, Rosendo, 2005, Historia de Guinea Ecuatorial. Período Pre-colonial. Impresiones Gráficas Alcorcón. Madrid.

Epstein, Dena J., 2003, Sinful tunes and spirituals: Black folk music to the Civil War. [1st ed. 1977].University of Illinois.

Fernández Moreno, Nuria, 1999, El sistema de parentesco y el culto a los ancestros en la etnia bubi de la isla de Bioko.Guinea Ecuatorial. Tesis doctoral presentada en la Universidad Nacional de Educación a Distancia, 1999.

García Cantús, Dolores, 2004, Fernando Poo, una aventura colonial española en el África Occidental 1778-1900. Departamento de Historia Contemporánea. Servei de Publicacions, Universitat de Valencia. 
Guillemar de Aragón, Adolfo, 1852, Opúsculo sobre la colonización de Fernando Poo y revista de los principales establecimientos europeos en la costa occidental del África. Imprenta Nacional, Madrid.

Goldie, Hugh, 1901, Calabar and its missions. A new edition, with additional chapters... Oliphant Anderson \& Ferrier, Edimburgh and London.

González Echegaray, Carlos, 1964, Estudios guineos Vol. I Filología 1956 y Vol. II Etnología 1964. Instituto de Estudios Africanos. C.S.I.C. Madrid.

Hampton, Barbara, 1979, "A Revised Analytical Approach to Musical Processes in Urban Africa”, African Urban Music, ed. Kazadi wa-Mukuna. Special issue of African Urban Studies. East Lansing, Michigan State University, 6 Winter 1979-1980, 1-16. Paper presented to the 24th Annual Conference of the Society for Ethnomusicology, 12 October, 1979, Montreal, P.Q., Canada.

Harrev, Flemming, 1987, Revised edition 1998 "Gumbe and the developement of Krio popular music in Freetown, Sierra Leone". Paper presented at LASPM's 4th International Conference, Accra, Ghana 1219 August 1987.

Harrev, Flemming, 1993, Revised edition 1997. "The origin of urban music in West and Central Africa" Presented at the 23rd World Conference of the International Council for Traditional Music, 16-22 June, 1993. Berlin.

Harrev, Flemming, 2001, "The Diffusion of Gumbe Assiko and Maringa in West and Central Africa". Paper presented at the Arts Council of the African Studies Association's $12^{\text {th }}$ Triennial Symposium on African Art by the Arts Council of the US African Studies Association, held at St Thomas, Virgin Islands 25-9 April 2001.

Holman, James, 1834, Voyage round the world, Volume I... The present Volume contains, Madeira, Teneriffe, St. Jago, Sierra Leone, Cape Coast, Accra, Fernando Po.... Smith, Elder, and CO., Cornhill, booksellers, by appointment, to their Majesties. London.

Hutchinson, Thomas J., 1861, Ten years wanderings among the ethiopians; with sketches of the manners and customs of the civilized and uncivilized tribes, from Senegal to Gaboon. Hurst and Blackett, Publishers, successors to Henry Colburn. London. Jones Mathama, Daniel, 1962, Una lanza por el Boabi. Casals. Barcelona.

Kingsley, Mary H., 1897, Travels in West Africa Congo francais, Corisco and Cameroons. London Macmillan and Co., Limited. New York.

Landaluze, Víctor Patricio, illustrator, 1881, Tipos y costumbres de la Isla de Cuba. Colección de Artículos. Por los mejores autores de este género. Obra ilustrada por D. Victor Patricio de Landaluze. Primera serie. Editor Miguel de Villa, Habana.

Larrea Palacín, Arcadio de, 1953, Algunas costumbres y mitos de los bujebas de nuestra Guinea continental. Archivos del Instituto de Estudios Africanos I.D.E.A. No 28, C.S.I.C., Madrid.

Lewin, Olive, 2000, Rock it Come Over, The folk music of Jamaica. University of the West Indies Press. Barbados, Jamaica, Trinidad and Tobago. 
Lipski, John M., 2004, "El español de América y los contactos bilingües recientes". Revista Internacional de Lingüistica Iberoamericana, № 4, 2004.

Long, Edward, 1774, The History of Jamaica. Or, General Survey of the Antient and Modern State of that Island, with Reflections on its Situation, Settlements, Inhabitants, Climate, Products, Commerce, Laws, and Government. 3 vols. London, Printed for T. Lowndes, IN Fleet-Street.

Lynn, Martin, 1984, “Commerce, christianity and the origins of the 'Creóles' of Fernando Po”. Journal of African History, 25, pp. 257 - 278. Printed in Great Britain. Cambridge.

Manfredi, Domingo, 1950, Ischulla La Isla. C.S.I.C. Instituto de Estudios Africanos. Madrid.

Martín del Molino, Amador, 1989, Los Bubi. Ritos y creencias. Centro Cultural HispanoGuineano. Malabo.

Martín del Molino, Amador, 1993, La ciudad de Clarence. Primeros años de la ciudad de Malabo, capital de Guinea Ecuatorial 1827-1859. Centro Cultural HispanoGuineano. Malabo.

Más, José, 1931, En el país de los bubi. Escenas de la vida en Fernando Poo. Segunda edición corregida y aumentada y con un prólogo de D. Miguel de Unamuno Editorial Pueyo, S.L. Primera edición, 1919.

Miller, Ivor, 2005, “Cuban Abakuá Chants, Examining New Linguistic and Historical Evidence for the African Diaspora”. En African Studies Review, Volume 48. Number 1, April, 2005.

Miller, Ivor, 2007, "Voice of the Leopard, Ivor Miller talks to Ned Sublette” http,//www. afropop.org/multi/interview/ID/116/Ivor+Miller+2007 [8 October 2009].

Miller, Ivor, L., 2009, Voice of the Leopard. African Secret Societies and Cuba. Foreword by Engr. Chief Bassey E. Bassey. Caribean Studies Series. Universsity Press of Missisipi/Jackson.

Miranda, Manuel M., 1903, Memorias de un deportado. Imprenta La Luz, San José.

Moreno Moreno, Jose A., 1948, "El Yangüe fernandino". En Africa, noviembrediciembre, pp. 83-84.

Morgades Besari, Trinidad, 2007, "Los criollos fernandino-krios de Guinea Ecuatorial $1^{a}$ parte”. El árbol del Centro. Centro Cultural Español de Malabo. No 5.2007. Guinea Ecuatorial.

Muñoz y Gaviria, José, 1950, Tres años en Fernando Poo. Viaje a África por el Vizconde de San Javier. Editor Urbano Manini. Madrid.

Navarro, Joaquín J., 1859, Apuntes sobre el estado de la costa occidental de Árica y principalmente de las posesiones españolas en el Golfo de Guinea.Imprenta Nacional. Madrid.

Ortiz, Fernando, 1995, Los instrumentos de la música afrocubana. El Ekué. Editorial Letras Cubanas. La Habana Separata sobre el tambor Ekué, incluido en la 1ª edición de 1952 y en la 2a edición de 1996.

Ortiz, Fernando, 1996, Los instrumentos de la música afrocubana. Editorial Música 
Mundana. 2 Vol. Madrid 1996. 1a Edición, La Habana 1952.

Panadés García, Fernando, “El dadji y la trascendencia del sentido de grupo”, Revista Oráfrica, número 3, abril de 2007. Ceiba Ediciones. Centros culturales españoles de Guinea Ecuatorial. Laboratorio de Recursos Orales. Barcelona.

Pepper, Herbert, 1958, Anthólogie de la vie africaine. Congo-Gabon. Libro que acompaña al triple álbum, 320 C 126/127/128] Disques Ducretet-Thomson, Paris.

Perrois, Louis, 1979, Arts du Gabon. Les arts plastiques du Bassin de l'Ogooué, ed. Arts d'Afrique Noire, Arnouville.

Rankin, F. Harrison, 1836, The white man's grave; a visit to Sierra Leone, in 1834. II. Vol. R. Bentley, London.

Rentik, Sonja, 2003, Kpanlogo Conflict, identity crisis and enjoyment in a Ga drum dance Student. Thesis of Department of musicology, University of Amsterdam.

Rios, Juan Miguel de los, 1844, Memorias sobre las islas africanas de España. Fernando Póo y Annobón. Premiadas por la Sociedad Económica Matritense. Compañía tipográfica. Madrid.

Roche y Monteagudo, Rafael, 1908,La Policía y sus misterios. Prólogo de R. Conté. La Habana, La Prueba.

Saluvet, B. Juan, 1930, Los Deportados a Fernando Póo en 1869. Memoria escrita por una de las víctimas. Segunda edición. Imp. De Jorge Lauderman. Habana. $1^{\mathrm{a}}$ Edición, 1892.

Sibthorpe, A.B.C., 1970, The History of Sierra Leone. 4th edition. London Routledge 1st Edition, 1868.

Sosa Rodriguez, Enrique, 1982, Los Ñáñigos. Ediciones Casas de las Américas. La Habana.

Sosa Rodriguez, Enrique, 1998, “La Leyenda Ñáñiga en Cuba, su valor documental”. En Tebeto, Anuario del Archivo Histórico Insular de Fuerteventura, No. 11, 1998, Cabildo de Fuerteventura, Servicio de Publicaciones.

Sundiata, Ibrahim Kamal, 1972, The Fernandino, labor and community in Santa Isabel de Fernando Po, 1827-1931. Northwestern University, Ph.D. History Modern.

Sundiata, Ibrahim Kamal 1974, "Prelude to scandal. Liberia and Fernando Po", 18801930. In Journal of African History, XV, I 1974, pp. 97-112. Printed in Great Britain.

Sundiata, Ibrahim Kamal, 1996, From Slaving to Neoslavery. The Bight of Biafra and Fernando Po in the Era of Abolition, 1827-1930. University of Wisconsin Press, Madison and London.

Unzueta y Yuste, Abelardo de, 1947: Historia geográfica de la isla de Fernando Poo. Madrid: Instituto de Estudios Africanos (I.E.A.), Consejo Superior de Investigaciones Científicas (CSIC), Madrid.

Usera y Alarcón, Jerónimo M., 1848, Memoria de la Isla de Fernando Poo. Imprenta de D. Tomás Aguado. Madrid.

Valdés Infante, Emilio, 1898, Cubanos en Fernando Poo. Horrores de la dominación española en 1897 a 1898. Imprenta El Fígaro. La Habana. 
Walker, James W. St. G., 1992, The Black Loyalists, The Search for a Promised Land in Nova Scotia and Sierra Leone, 1783-1870. University of Toronto Press.

Zamora Loboch, Miguel, 1962, Noticia de Annobón. Geografía, Historia y Costumbres. Publicaciones de la Diputación Provincial de Fernando Poo. Santa Isabel 1962.

\section{Oral Communications}

Borubú, Juan María: personal communication on the construction of the kunké drum (Bubi).

Cachina, Pedro: personal communication on instruments and dances (Annobonese).

Cervera Liso, Desiderio: personal communication on instruments and recordings Annobonese songs and dances.

Dougan. Ana María: personal communication on krio's history and culture in Bioko.

Jalloh Anthony Zachariah (Seydu): personal communication on kio's music in Freetown and gumbé played by his grandfather Ebenezer Calender.

Kinson, Diego: personal communication on bonkó rite and kunki dance of Fernandino creoles.

Kinson, Teobaldo: personal communication on rituals between Fernandino creoles.

Leon, Paulino (Lavi): personal communication on instruments and recordings songs and dances (Annobonese).

Makole, Felicísima: personal communication on funerary rite of bonkó.

Medina Bestué, Cornelio: personal communication on instruments and recordings Annobonese songs and dances.

Morgades Besari, Trinidad: personal communication on krio's history and culture in Bioko.

Meté, Dolores: personal communication on old Bubi customs.

Muatetema Muelachuá, Donato: personal communication on Bubi music.

Murcia, Juan: personal communication on instruments and recording Annobonese Cumbe dance.

Panadés, Cipriano: personal communication on instruments and dances and recording Annobonese songs.

Osá, Felipe: personal communication on Fang instruments and on Abakuya dance and songs.

Teruel Mandrá, Hipólito (Manga): personal communication on instruments and recordings Annobonese songs and dances.

Tomé, Santos (Pecua): personal communication and recording ritual and dance Mamahe (Annobonese).

Vivour Lolin, Bankole: personal communication on instruments, music, rites and history of Fernandino creoles .

Yayé Villalba, Abraham: personal communication and recording song at the Claretianos church. 